\title{
THE INFLUENCE OF VARYING RATIO OF COWPEA HUSK AND MAIZE MILLING WASTE ON THE FEED INTAKE, PQROTEIN AND ENERGY UTILIZATION BY THE GOAT.
}

\author{
A.A. ADELOYE \\ Dept. of Animal Production, University of Ilorin, Ilorin, Nigeria. \\ Received 6 Oct 1994; Accepted 5 November 1994
}

\section{ABSTRACT}

The acceptability and efficacy of. combinations of cowpea husk (CH) and maize milling waste (MMW) as feed for the goat were tested. The experiment, in a $4 \times 4$ Latin square design involved digestion trials with 4 West African dwarf grower goats weighing 8.2 to 9.6 kg. and about 4 months old. There were 3 experimental diets made up of $\mathrm{CH}$ and MMW in $25: 75,50: 50$ and $75: 25$ ratio of mixture. The control diet was 60 percent chopped Pennisetum purpureum plus 40 percent concentrate ration. The animals were fed at 5 percent of body weight. All trials lasted 80 days. Parameters for assessment were dry matter intake, protein and energy intakes and utilization. Feed intake values (\%of body weight) in all experiemental diets were higher than 3 percent and increased with increasing levels of cowpea husk. Only the intake of $4.38 \%$ of body weight from $75: 25$ CH-MMW supported weight gain. Increases in MMW in the experimental diets resulted in significant $(\mathrm{P}<0.05)$ increases in dry matter digestibility. The crude protein intake and digestion increased with increasing inclusion of cowpea husk, but intake and utilization were not adequate at CH-MMW 25:75 and 50:50. The energy intake and utilization increased $(\mathrm{P}<0.05)$ across the treatment. Increasing levels of cowpea husk enhanced dry matter, energy intakes and energy utilization. Decreasing levels of cowpea, consistent with increasing MMW improved dry matter digestibility but not dry matter intake. The high crude fibre of cowpea husk is implicated. The utilization of the available energy in the mixture is limited by protein intake.

Key Words: crop-wastes, cowpea husk, maize milling waste, feed utilization, goat.

\section{INTRODUCTION}

Feeding has been known to constitute 80 percent of the total cost in animal production. The increasing need to minimize the finishing cost of animal products has culminated in sourcing alternative feed-stuffs for livestock production. The crop by- products have been the object of focus. In view of the differing nutrient characteristics of the crop by-products, and therefore the complementary effect of one by-product on the other, an efficient livestock feed from these by-products requires a correct combination of the crop wastes in order to provide adequate quantities of the needed nutrients.

Maize is predominantly the cereal crop of Southern Nigeria but it is practically cultivated throughout Nigeria. The cowpea (Vigna unguiculata Walp) or bean as it is popularly called is indigenous to West Africa. Maize and cowpea are widely cultivated in the middle belt of Nigeria and are often involved in crop rotation or interplanted in Southern Nigeria. So, the use of the by-products from these sources is a step towards enhancing man's dependency on these crops. The maize milling waste is a by-product in the processing of corn flour. It consists of the testa or seed coat or bran of maize grain. However, some part of the embryo or endosperm may be found in the waste product, all depending on the efficiency of milling. The waste has been shown by Ayoade (1987). to improve the intake and digestibility of Pigeon pea pods by the goat in Malawi. The cowpea husk is a legume by-product. It is that portion of the whole pod which on threshing remains as the waste when the seeds are removed. It has been fed to the goat in Nigeria by Adebowale (1981) and found to have a 
depressing effect on feed intake but a preliminary study in Ilorin, Nigeria (Adeloye, unpublished) indicate that the cowpea husk is well accepted by the goat.

This study evaluates the effect of varying ratio of combination of maize milling waste and cowpea husk on the feed intake and protein and energy utilization by the goat.

\section{MATERIALS AND METHOD}

Four grower West African dwarf goats aged about 4 months and weighing 8.2 to $9.6 \mathrm{~kg}$ were involved in a $4 \times 4$ latin square experiment to assess the intakes and digestibilities of feeds formulated from cowpea husk and maize milling waste. There were 3 experimental diets made up of the varying rations of cowpea husk and maize milling waste as presented in Table 1 . The control diet comprised of 60 percent daily cut and chopped elephant grass (Pennisetum purpureum) plus 40 percent of concentrate ration. The concentrate ration was made up of 3 parts of maize and 2 parts of soybean cake. Daily feed allowance was at 5 percent of body weight. The study was conducted at the University of Ilorin, Nigeria.

The animals were housed individually in separate metabolic cages suitably constructed with slated floor for the collection of faeces and urine. Each digestion trial involved an initial period of 15 days to allow the animals adjust to confinement and the diet followed by a collection period of 5 days. The faeces were collected in polythene sheets while the urine was collected in plastic containers which previously had $5 \mathrm{ml}$ of $(5 \% \mathrm{v} / \mathrm{v})$ acetic acid. Feed refusals were quantified to estimate daily feed intakes. The faeces voided daily were weighed, dried in a force draught oven at $105^{\circ} \mathrm{C}$ and bulked for each animal for chemical analyses. The volume of urine voided by each animal was measured and 10 percent aliquots of daily collections were bulked for chemical analyses. The experiment lasted 80 days.

The feeds and faeces samples were analysed for the nutrient components by the A.O.A.C. (1985) methods. Crude protein (NX6.25) was determined by the Markham's microkjeldahl method (Markham, 1942), ether extract by the Soxhlet extraction method, crude fibre by the trichloro-acetic acid method and energy by the ballistic bomb calorimetry.

The data for each response criterion were subjected to analysis of variance appropriate to the Latin square design (Steel and Torrie, 1980) and the treatment means tested (Duncan, 1955).

\section{RESULTS}

The nutrient compositions of the treatment diets and crop by- products are presented in Table1. Data from this table put the control diet of 40 to 60 concentrate grass mixture at $15.05 \%$ crude protein, $30.49 \%$ crude fibre and $5.38 \mathrm{Kcal} / \mathrm{g}$ of gross energy. The variations in the composition of the experimental diets are reflections of the nutrient contents of the dietary components.

The liveweight changes, feed intake performance, some nutrient intakes and their utilizations are presented in Table 2. Feed intake values ( $\%$ of bodyweight) increased significantly $(P<0.05)$ with increasing levels of cowpea husk $(\mathrm{CH})$. Decreasing levels of cowpea husk, consistent with increases in the maize milling waste (MMW) in the experimental diets resulted in increased values of dry matter digestibility. Feed intakes from the control and the 75:25 CH-MMW mixture produced positive weight balances.

The intake and utilization of crude protein at the 75:25 CH-MMW mixture compared well $(P>0.05)$ with corresponding values of the control diet. These parameters increased across the treatments with increasing cowpea husk inclusion but the values were lower $(\mathrm{P}<0.05)$ than those of the control diet at the 25 and 50 percent cowpea husk levels.

The gross energy intake, digestible energy and metabolizable energy values in all the experimental diets were superior $(P<0.05)$ to those of the control diet. These parameters increased significantly $(P<0.05)$ across the treatments. 


\section{DISCUSSION}

The dry matter intake values (\% of body weight) in all the treatments agree with those of Akinsoyinu (1985) for goat, Elliot and Topps (1963) and Adu and Lakpini (1983) for sheep. The observation on feed intake values in respect of the level of the maize milling waste in CH-MMW mixtures negates the finding of Ayoade (1987) on the effect of the maize by-product on pigeon pea pods. However, the influence of the cereal by-product on dry matter digestibility agrees with the report of Ayoade (1987) and could be due to increases $(P<0.05)$ in crude fibre intakes consequent on cowpea husk inclusion in the dicts. The maize milling waste could therefore combine with these similar 'husk or pod' by-products from different legume plants to effect the same pattern of dry matter digestibility but the pattern of feed intake may be quite different. In contrast to a depression of feed intake observed by Adebowale (1981), the increasing levels of cowpea husk enhanced the intake of dry matter in this study.

The efficacy of the 75:25 CH-MMW mixture to produce a positive weight gain is suggested to be due to the combined effects of the crude protein content of the diet and the high dry matter intake. The negative weight balances on 25:75 and 50:50 CH-MMW mixtures call for a look into the nutrient intakes from the experimental diets. Crude protein is inadequate in the 25:75 and 50:50 CH-MMW mixtures but an increase in the digestibility of protein with higher dietary protein levels as reported elsewhere (Stobo and Roy, 1973) is noticeable in this study.

On the strength of the metabolisable energy (ME) $\left(\mathrm{Kcal} / \mathrm{d} / \mathrm{W}^{0.75} \mathrm{~kg}\right)$ obatinable from the control diet and the recommendations of Akinsoyinu (1974) for goat, Olatunji (1974), Adu and Olaloku (1976) and NRC (1985) for sheep, the ME value from the 75:25 CH-MMW mixture in this study more than satisfies the energy requirement for the observed growth rate. Therefore the utilization of the energy available for tissue metabolism in this study is limited by the amount of the crude protein in the dietary mixture.

\section{ACKNOWLEDGEMENT}

The author acknowledges the assistance of Messrs Akanji Oladunni, Tosin Hungbeji and Dare Fabunmi of the Department of Animal Production in the collection of the data and chemical analyses.

\section{REFERENCES}

ADEBOWALE, E.A. (1981) The Feeding value of cowpea husks (Vigna unguiculata Walp) in rations for goats. International Livestock Centre for Africa (ILCA) 31 (2):141-145.

ADU, I.F. and LAKPINI, C.A. M. (1983) The utilization of dried poultry waste as protein supplement for growing Yankassa sheep. J. Anim. Prod. Res. 3: 49-56

ADU, I.F. and OLALOKU, E.A. (1976) Studies on feed intake of the West African dwarf sheep. E. Afr. Agric. For. J. 42: 224-230

AKINSOYINU, A.O. (1974) Siudies on protein and energy utilization by the West African dwarf goats. Ph.D. Thesis, University of Ibadan, Nigeria.

AKINSOYINU, A.O. (1985) Nutrient requirements of sheep and goats in Nigeria. In:Small Ruminant Production in Nigeria. Proceedings of National Conference on Small Ruminant Production, Zaria, Nigeria. 6 - 10 October, pp 111-125.

AOAC (1985) Officisl Methods of Analysis, 13th edition. Association of Official Analytical Chemists, Washington, D.C.

AYOADE, J.A. (1987) The effect of maize bran on voluntary intake and digestibility of Pigeon pea (Cajanus cajan) pods by goat, IN: "Overcoming contraints to the efficient utilization of agricultural by-producls as animal feed", Proceedings, fourth Annual workshop, African Research Network for Agricultural by-products (ARNAB) ILCA, 1989: 267-271

DUNCAN, D.B. (1955) Multipie range and multiple F-test, Biometrics, 11: 1- 42

ELLIO'T, R.C. and J.11., TOPPS (1963) Studies on protein requirements of ruminants. IBrit. J. Nut. 17: $539-547$

MARKHAM, R. (1942): A stcam distillation apparatus suitable for microkjeldahl analysis J3iochem J. 36: 790 $-701$

NRC. (1985) Nutrient requirement of sheep. 6th Revised edn. National Academy Press, Washington, D.C. pp 45.

OY.ATUNII, O. (1974) Digestion and utilization of carbohydrate and energy in West African dwarf sheep Ph.D. Thesis. University of Ibadan, Nigeria.

STEEL, R.G.D. and TORJIE, J.II. (1980) Principles and procedures of statistics, McGraw Ilill Book Co. Inc. N.Y.

STOBO, I.J.F. and J.H.B. ROY (1973) The protein requirement of the ruminant calf. 4 . Nitrogen balance sudies on rapidly growing calves given diets of different protcin contents. Brit. J. Nut. 30: $113-125$. 


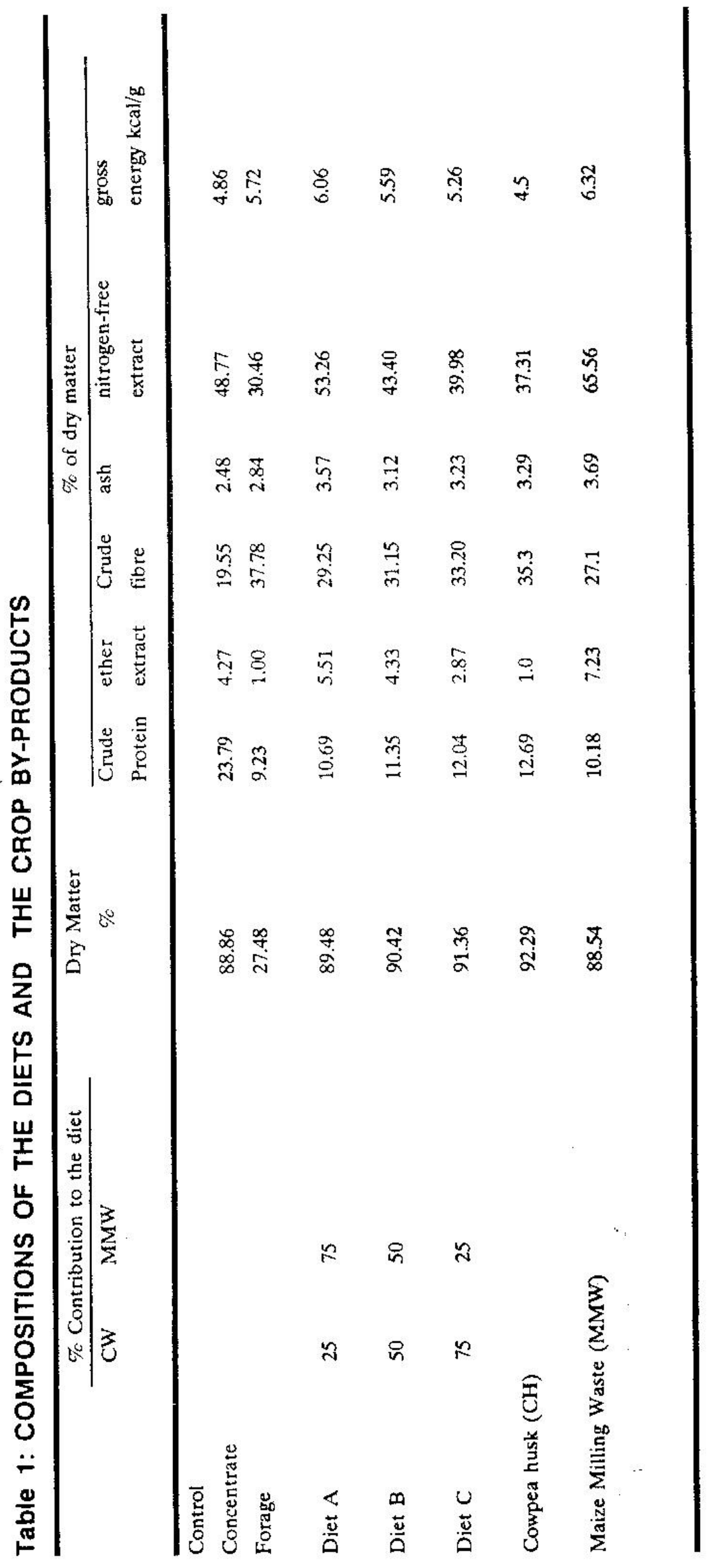


Table 2: LIVEWEIGHT CHANGES, FEED AND NUTRIENT UTILIZATION BY GOAT FED VARYING COMBINATIONS OF COWPEA HUSK AND MAIZE MILLING WASTE.

Parameters Control

diet
A

Experimental diets

\begin{tabular}{|c|c|c|c|c|}
\hline Liveweight, $\mathrm{kg}$ & $8.14 \pm 0.9$ & $8.75 \pm 1.0$ & $9.1 \pm 0.8$ & $8.69 \pm 0.9$ \\
\hline initial & $8.25 \pm 1.4$ & $8.44 \pm 1.0$ & $8.95 \pm 1.0$ & $9.10 \pm 0.8$ \\
\hline final & $8.25 \pm 1.4$ & $8.44 \pm 1.0$ & $9.95 \pm 1.0$ & $9.10 \pm 0.8$ \\
\hline average & $8.2 \pm 0.1$ & $8.6 \pm 0.2$ & $9.63 \pm 0.1$ & $8.9 \pm 0.2$ \\
\hline gain & $0.11 \pm 0.2$ & $0.31 \pm 0.19$ & $0.15 \pm 0.13$ & $0.41 \pm 9.31$ \\
\hline growth rate; $g / d$ & 20 & -60 & -30 & 80 \\
\hline $\begin{array}{l}\text { Dry matter intake } \\
\qquad \mathrm{g} / \mathrm{d}\end{array}$ & $229.51^{a} \pm 50.3$ & $284.08^{b} \pm 62.4$ & $348.42^{\mathrm{C}} \pm 5.5 .5$ & $389.95^{\mathrm{c}} \pm 42.2$ \\
\hline $\begin{array}{l}\text { DMI as \% of body } \\
\text { weight }\end{array}$ & $2.8^{\mathrm{a}}$ & $3.3^{b}$ & $3.86^{\mathrm{C}}$ & $4.38^{\mathrm{d}}$ \\
\hline $\begin{array}{l}\text { DM digestibility; } \% \\
\text { Crude protein } \\
\text { (Nx6.25) }\end{array}$ & $56.75^{\mathrm{a}} \pm 3.4$ & $69.62^{c} \pm 2.5$ & $68.38^{c} \pm 2.7$ & $63.76^{b} \pm 1.2$ \\
\hline $\begin{array}{l}\text { - intake. } g / d \\
\text {-digested, g/d } \\
\text {-ratained, g/d } \\
\text {-net protein }\end{array}$ & $\begin{array}{l}43.92^{b c} \pm 5.1 \\
33.97^{b} \pm 9.1 \\
22.86^{c} \pm 5.6\end{array}$ & $\begin{array}{l}30.37^{\mathrm{a}} \pm 5.2 \\
24.47^{\mathrm{c}} \pm 7.3 \\
20.97^{\mathrm{a} b} \pm 4.2\end{array}$ & $\begin{array}{l}39.63^{\mathrm{b}} \pm 6.3 \\
32.31^{\mathrm{b}} \pm 5.3 \\
22.07^{\mathrm{b}} \pm 3.8\end{array}$ & $\begin{array}{r}46.95^{c} \pm 5.1 \\
38^{c} \pm 4.2 \\
26.59^{c} \pm 3.5\end{array}$ \\
\hline $\begin{array}{l}\text { utilization \% } \\
\text { Crude fibre }\end{array}$ & $55.04^{\mathrm{a}} \pm 6.9$ & $74.1^{b} \pm 4.7$ & $55.74^{\mathrm{a}} \pm 4.1$ & $56.31^{\mathrm{a}} \pm 7.7$ \\
\hline -intake $\mathrm{g} / \mathrm{d}$ & $58.24^{a} \pm 4.7$ & $83.09^{\mathrm{b}} \pm 3.6$ & $108.77^{\mathrm{c}} \pm 7.3$ & $129.46^{\mathrm{d}} \pm 4.1$ \\
\hline Energy & & & & \\
\hline $\begin{array}{l}\text {-intake, } \mathrm{kcal} / \mathrm{d} \\
\text {-digestible }\end{array}$ & $1178.56^{\mathrm{a}} \pm 40.1$ & $1721.51^{b} \pm 62.6$ & $1947.66^{b} \pm 31$ & $2051.11^{\mathrm{c}} \pm 22.2$ \\
\hline $\begin{array}{l}\text { energy, } \mathrm{kcal} / \mathrm{d} \\
\text {-metabolizable }\end{array}$ & $913.43^{\mathrm{a}} \pm 26.7$ & $1447.76^{b} \pm 68.1$ & $1594^{b c} .8 \pm 62.4$ & $1625.65^{\mathcal{C}} \pm 62.9$ \\
\hline $\begin{array}{r}\text { energy kcal/d } \\
-\mathrm{Kcal} / \mathrm{d} / \mathrm{Wkg}^{0.75}\end{array}$ & $\begin{array}{c}749.01^{\mathrm{a}} \pm 21.9 \\
154.59^{\mathrm{a}}\end{array}$ & $\begin{array}{c}1187^{\mathrm{b}} .16 \pm 57.9 \\
236.39^{\mathrm{b}}\end{array}$ & $\begin{array}{c}307^{\mathrm{b}} .74 \pm 21.5 \\
239.2^{\mathrm{b}}\end{array}$ & $\begin{array}{r}1333^{b} .03 \pm 49.9 \\
258.69^{b}\end{array}$ \\
\hline
\end{tabular}

$\pm: \quad$ Standard deviation

a,b,c, = values along the same row with difterent superscripts are statistically different $(\mathrm{P}<0.05)$. 